\title{
Abolition of initial wage compensation during sick leave
}

When malfunction of control mechanism is semi-repaired by politicians

\section{Martin Štefko}

\section{(2) OpenEdition}

\section{Journals}

Electronic version

URL: https://journals.openedition.org/rdctss/1440

DOI: $10.4000 /$ rdctss. 1440

ISSN: 2262-9815

\section{Publisher}

Centre de droit comparé du travail et de la sécurité sociale

Printed version

Date of publication: 1 December 2019

Number of pages: $220-223$

ISSN: $2117-4350$

\section{Electronic reference}

Martin Štefko, "Abolition of initial wage compensation during sick leave", Revue de droit comparé du travail et de la sécurité sociale [Online], 4 | 2019, Online since 01 November 2021, connection on 11 November 2021. URL: http://journals.openedition.org/rdctss/1440 ; DOI: https://doi.org/10.4000/ rdctss. 1440

\section{(c) $(1) \odot$}

Revue de droit comparé du travail et de la sécurité sociale est mise à disposition selon les termes de la Licence Creative Commons Attribution - Pas d'Utilisation Commerciale - Pas de Modification 4.0 International. 


\section{MARTIN ŠTEFKo}

FACULTY of LAW, Charles University

\section{ABOLITION OF INITIAL WAGE COMPENSATION DURING SICK LEAVE* \\ WHEN MALFUNCTION OF CONTROL MECHANISM IS SEMI-REPAIRED BY POLITICIANS}

After 50 years ${ }^{1}$ of reliance on public insurance or social security programmes, the Czech legislature has enacted a statutory wage continuation payments programme in Section 192 et seq. of the second Czech Labour Code of 2006 (Sick Pay Reform). Instead of statutory sick pay financed from the state budget from collected premiums on sick leave insurance, employers are obliged to pay wage compensation due during the first 14 calendar days for time away from work for illness. Employees on sick leave are entitled to receive $60 \%$ of their reduced ${ }^{2}$ salary for time missed save the initial exclusion period and the termination of employment relationship. The right to wage compensation was composed as a statutory right with no space for employers' vacation or sick pay polices that would lay out additional requirements or criteria to limit contingencies outside of the employers' control. In addition, sick pay has to be provided out of the general assets of a business; payments are made the same way as wages are paid.

Employers had feared that Sick Pay Reform. In the understanding of closely held corporations, Sick Pay Reform has encouraged their employees to go to cottage every summer. It was simply too tempting for them to describe cottage vacations as periods of convalescence from illness. Thus, the law stipulated a mandatory three-day period during which employers were to hold payments, a so-called initial exclusion period. The exclusion of sick pay had always been a prolific source of litigation and criticism, and a regular agenda among social democrats and communists. The new statute that abrogated the initial exclusion period is under Czech standards of laws citation quoted as Act. no. $32 / 2019$ Collection (hereinafter referred to in this article as Act on Deleting Exclusion Period - ADEPT). Abolishing the exclusion period from 1 July 2019, the Act ordered employers to pay wage compensations for the first three days of sick leave in the same amount as they pay for the 4th to 14th day of sick leave. It is ironic that the social democrats, who finally managed to abolish the infamous initial exclusion period in this year, are close to oblivion after losing several elections in a row.

* This article has been written and published thanks to the financial support of the grant project «Soukromé právo a výzvy dneška» [Civil Law and Challenges of Today], identity code Q03.

1 A legal predecessor of the described regulations was set forth in Sections 1154b and 1156 of General Civil Code proclaimed in 1811. The wage continuation payments lasted in theory until 1956, when the former section was abolished by Act no. 54/1956 Coll. on Sick Leave Insurance. The latter was abrogated by Section 279 I para. 1 Act no. 65/1965 Collection.

2 Respective wage compensation was reduced in the same way as sick leave benefits paid under public mandatory sick leave insurance were calculated. This means that wage compensation was reduced every time regardless of increased or decreased amount of services performed by the sick employee. 


\section{I - ON THE EDGE OF CONSTITUTIONALITY}

The right-centre government's primary concern to eliminate mischief in sick pay usage is older' than Sick Pay Reform. However, since 1989, respective state agencies have never been able to decrease what was considered to be a significant number of cheating temporary disabled employees. The initial exclusion of sick pay enacted in Sick Leave Insurance Act, which was designed to accomplish this objective, was put in force in 2007. When the Constitutional Court of the Czech Republic addressed the issue of the initial exclusion of sick pay, it held it is unconstitutional ${ }^{3}$. The court based its reasoning on the universal mandatory duty of employees to contribute to the public sick leave scheme, the surplus of the sick leave insurance scheme, and the apparent legislative intent to squeeze out additional revenue for being for other spending than that connected with sick leave insurance.

In 2009, the initial exclusion of sick pay returned in valid law again ${ }^{4}$, this time in the already mentioned Section 192 of the Labour Code. The legislature made minor adjustments in Sick Pay Reform, such as relabelling employees' insurance payments, providing minor exceptions to the coverage, and slightly decreasing employers' premiums paid on behalf of their employees. Sick Pay Reform was accompanied with extensive notification duties and employers' limited competence to investigate employees on sick leave, all of which was designed to accomplish the same ultimate objective to cure public finances. However, most problems remained unsolved. Wage compensation during sick leave is neither considered by law to be deferred compensation, nor are employees whose coverage terminates allowed to purchase continuation coverage for a limited period of time. The real trap for employees continued to lie in statutory provisions which result in an employee forfeiting his or her sick leave payments upon voluntary or involuntary termination of his or her employment relationship.

Oddly enough, the Constitutional Court held the reform of 2006 to be constitutional this time. First of all, the judges gave up their previous judicial activism. Despite similarities with the previous judgment (i.e. ill employees are paid less, Sick Pay Reform takes revenge on every and each sick employee regardless of whether they are cheating or not, and the legislature's ignorance of the Constitutional Court opinion raised in the first judgment), judges were satisfied with what seems, even today, to be theoretical changes with no real impact on employees' tax burden 5 .

\section{II - EMPLOYERS DOOMED TO FAIL}

Apart from the goal to re-balance the public budget in a broad sense, the second objective of the Sick Pay Reform was to stop the abuse of welfare benefits.

Where state officials failed, the right-centre government believed that employers will do better. The Sick Pay Reform authorized both private and public employers to police their ill employees during the first 14 days of their incapacity to work. Provided that employers identified a serious breach of employees' duty to be present at a certain place in certain hours, they could cut wage compensation or even dismiss such an employee. However, for

3 Judgment docket file no. Pl. ÚS 2/08.

4 It was brought by Act no. 305/2008 Collection.

5 Judgment docket file no. PI. ÚS 54/10. 
obvious reasons employers were not allowed to investigate employees' health status, rather they could only enquire whether ill employees were present at a reported flat or house. Unfortunately, employers were not even given the same inspection competencies that state officials of Czech Social Security Administration have enjoyed for decades. Inevitably, employers faced a rough truth. These claims were difficult for employers to police without offensive intrusion into the private lives of allegedly sick recipients.

The audit problem was exacerbated by the aftermath of court decisions. Although wage compensation cut happened quite often, all dismissal cases decided by upper courts proved that employers can hardly fire employees for violating duties connected to wage continuation payments. Employees declared to be temporarily disabled to work are obliged to provide for their employers sufficient cooperation. In practice, employers demanded that employees shall provide notification of his or her place of dwelling during sick leave. However, the Supreme Court concluded that no employee can be fired solely because of neglecting such a notification duty ${ }^{6}$. In the Supreme Court's judgment of 17 December $2015^{7}$, the employer was not even able to deliver the notice of dismissal to the employee properly, and the legal action was not enforceable.

\section{III - TOWARD CANCELLATION OF THE INITIAL EXCLUSION PERIOD}

A couple of subsequent amendments mitigated what was in politicians' speeches considered to be hardship suffered by all insureds. Several amendments limited the initial exclusion period in its length and set forth additional exceptions to its application. In the emblematic $10^{\text {th }}$ year of its existence, the social democrats (who have suffered several defeats in a row and are close to oblivion) with support of Communistic MPs have finally managed to abolish the infamous initial exclusion period.

The social democrats used the same main argument as always: «lt is an unjust punishment for illness. People are afraid to get sick» ${ }^{8}$. A total of 128 of 189 Czech MPs voted in favour of the abolishing bill. Their involvement was inevitable due to apparent reluctance of courts to change the policy passed by Parliament 10 years ago. Sick leave insurance is and for dozen of years has been in surplus. Collected premiums that were not used to pay benefits for the public scheme were digested by other mandatory state expenditures not connected with sick leave. The ADEPT seems to confirm that even Czech Parliament takes now for granted that wage continuation payments are not a gratuity or a gift, but is additional wage for services performed. It involves a reasonable arrangement to secure the wellbeing of ill employees and the continuance of harmonious relations between employers and employees on one hand, and employees and their dependent family members on the other. From July 2019, employees will be entitled to $60 \%$ of their reduced salary from the first day of sick leave.

6 Judgment of 15 October 2015, docket file no. 21 Cdo 5126/2014.

7 Docket file no. 21 Cdo 630/2015.

8 Social democrat Kateřina Valachová represented to news reporters: https://www.idnes.cz/zpravy/ domaci/nemocenska-prvni-tri-dny-zakon-snemovna-vlada-cssd-ano.A181031 090228 domaci kop. Communist deputy chief Pavel Kováčik supported the bill saying: «For those who don't have reserve funds, those first three days are crucial». 


\section{CZech Republic}

\section{Conclusion}

The unpaid first three days of sick leave has been controversial since its inception in 2008. The government succeeded in its second attempt and for almost 10 years kept the initial exclusion period in public sick leave insurance. In its second judgment, the Constitutional Court supported the notion mentioned in its previous decisions, and in pension insurance law as well, that it did not view an insured's right to sick pay as a property right protected under the Czech Constitution. Generally, sick leave benefits and wage continuation payments are contingent on an illness occurring during the course of employment.

ADEPT has in July of 2019 ended this time, but it provided absolutely no answer to the primary incentive of why the initial exclusion period was set forth: the high number of temporary disabled employees. Hence, ADEPT can be understood as a confirmation of welfare rights veneration on one hand, however, one the other, the government continues to be unable, despite of all its efforts, to close the door to abuse on the side of anticipated hundreds of employees who treat their salaries as excludable insurance receipts.

The modern Czech welfare state that was not able to conquer mischief connected with sick pay decided in 2009 to share the check burden with employers, who were given a minor reduction of social security contributions in exchange. It was thought that employers will succeed where the Czech Social Security Administration failed. After several court decisions it is clear that even the best equipped employers hardly win dismissal cases on reasons not connected with employees' work duties. Because not all MPs were in favour of ADEPT, the cause can easily become an issue for the next government that will seek to reverse the anticipated increase in incidences of sick leave, which is a burden on both employers and the state. Given the upcoming economic climate where Czech businesses are struggling to be more competitive with foreign businesses, employee benefits can be once again looked at more extensively than before. 